\title{
Pemahaman Kepatuhan Hukum dan Disiplin terhadap Tata Tertib Sekolah dengan Tanggung Jawab Belajar
}

\author{
Alwi Sahlan ${ }^{1 *}$, Mohamad Abduh $^{2}$, Suidat $^{2}$ \\ ${ }^{1}$ SMP Mutiara Depok, Indonesia \\ ${ }^{2}$ STKIP Arrahmaniyah, Indonesia
}

\begin{abstract}
Abstrak - Tanggung jawab belajar dan disiplin terhadap tata tertib sekolah terlihat memprihatinkan, fakta-fakta yang dapat kita lihat pada diri siswa yang menggambarkan ketidak patuhan siswa Penelitian ini bertujuan untuk memperoleh data empiris mengenai:

pemahaman kepatuhan hukum dan disiplin terhadap tata tertib sekolah dengan tanggung jawab belajar siswa kelas IX di SMP Mutiara Depok. Penelitian ini dilaksanakan bulan Juli sampai dengan bulan Oktober 2020, Metode yang digunakan dalam penelitian ini adalah metode korelasi. Populasi dalam penelitian ini adalah siswa SMP Mutiara Depok, peneliti hanya mengambil $80,36 \%$ dari jumlah populasi sehingga hanya 90 siswa, Instrumen yang digunakan adalah menggunakan butir test dan angket skala perilaku. Teknik analisis data dalam penelitian ini menggunakan analisis regresi berganda. Pengujian hipotesis dilakukan dengan korelasi Product Moment. Dari hasil perhitungan diperoleh $r_{\mathrm{xy}} \mathrm{X}_{1}$ dan $\mathrm{X}_{2}$ bersama-sama dengan $\mathrm{Y}$ sebesar 0,9942. Karena $r_{\text {hitung }}$ lebih dari $r_{\text {tabel }}(0,9942>0,205)$, maka dapat disimpulkan bahwa terdapat hubungan signifikan. Koefisien determinasi sebesar 98,85 . Dengan demikian konstribusi variabel $X_{1}$ dan $X_{2}$ terhadap Y sebesar 98,85\%. Tingkat keberartian hubungan kedua variabel dilakukan dengan uji-t. Dari hasil perhitungan diperoleh $t_{\text {hitung }}=86,921$. Dengan demikian $t_{\text {hitung lebih dari } t_{\text {tabel }}}$ $(86,921>1,987)$. Perbandingan kedua nilai $t$ tersebut menunjukkan adanya pengaruh yang berarti.
\end{abstract}

Kata kunci:

Kepatuhan Hukum,

Disiplin,

Tanggung Jawab.

(c) (i) (2) Author(s) agree that this article remains permanently open access under the terms of the Creative Commons Attribution-ShareAlike 4.0 International License

Identitas Artikel:

Sahlan, A., Abduh, M., \& Suidat, S. (2021). Pemahaman Kepatuhan Hukum dan Disiplin terhadap Tata Tertib Sekolah dengan Tanggung Jawab Belajar. Jurnal Citizenship Virtues, 1(1), 27-34.

\section{PENDAHULUAN}

Mengapa siswa harus patuh terhadap hukum dan tata tertib sekolah? Yang pertama agar tercipta perdamaian, ketertiban dan keteraturan. Jika ketertiban dan keteraturan tercipta maka diharapkan mampu menunjang proses belajar mengajar yang optimal. Apa yang terjadi jika hukum tidak dipatuhi? Maka akan terjadi kekacauan di mana mana akibat satu sama lain bertikai akibat benturan kepentingan antar sesama individu.Yang kedua karena hukum itu sebenarnya ibarat pagar bagi orang yang tidak terbiasa disiplin ia merasa diri dibelenggu akan tetapi bagi orang yang disiplin

*Corresponding author

E-mail: sahlan.alwi@gmail.com 
ia bagaikan pelindung dan pembatas agar tidak. Kunci suksesnya kegiatan belajar mengajar di sekolah bermula dari kepatuhan siswa akan hukum tata tertib sekolah dan tanggung jawab belajar. Karena patuh merupakan suatu kondisi di mana seseorang mengerti apa yang ada dalam pikiran, keinginan, harapan, serta ucapannya dan paham dengan apa yang sedang dan akan dilakukannya sekaligus kesanggupan diri dalam mengikuti berbagai keputusan dengan rasa bertanggung jawab, serta siap menerima berbagai kemungkinan atau konsekuensi dalam kehidupan. Fakta-fakta yang dapat kita lihat pada diri siswa yang menggambarkan ketidakpatuhan siswa; adanya siswa yang sering terlambat (Fiana, Daharnis \& Ridha, 2013), tidak membuat pekerjaan rumah (Sujarwo, 2020), mencoret coret bangku, tidak biasa antre, pada saat upacara bendera tidak tertib, tidak berpakian dengan rapi, sering datang terlambat, abai dan sering tidak mengerjakan tugas (Hernawati, 2017).

Di SMP Mutiara Depok sebelumnya memang sudah ada tata tertib sekolah. Tanggung jawab belajar dan disiplinpun sudah ada namun belum optimal. Penulis bukan ingin meningkatkan itu namun ingin tahu apakah ada hubungan signifikan antara materi PPKn yaitu materi pemahaman kepatuhan hukum di kelas 9 dan disiplin terhadap tata tertib sekolah dengan tanggung jawab belajar siswa. Upaya mengetahui tingkat signifakansi itu maka peneliti perlu memberikan materi pemahaman kepatuhan hukum. Pelaksanaan pendidikan Kepatuhan Hukum dalam mata pelajaran Pendidikan Kewarganegaraan adalah pelaksanaan yang wajib melalui pembelajaran dalam kelas yang saat ini telah dilaksanakan dan dinilai oleh guru (Damri, Putra \& Kom, 2020; Latifah, 2014). Pada mata pelajaran yang lain, pendidikan kepatuhan hukum dapat diintegrasikan dalam standar kompetensi dan kompetensi dasar dari mata pelajaran yang relevan. Pemilihan cara dan bentuk pendidikan Kepatuhan Hukum di sekolah dibebaskan kepada satuan pendidikan sesuai dengan visi dan misi masing-masing satuan pendidikan. Untuk mencapai hal tersebut, komitmern menegakkan tata tertib sangat menentukan dalam pembentukan perilaku siswa agar sesuai dengan yang diharapkan oleh sekolah (Narumi \& Pudjiastuti, 2017).

Berdasarkan Standar Kompetensi dan Kompetensi Dasar Pendidikan Kewarganegaraan (PKn) untuk SMP yang dikeluarkan oleh Departemen Pendidikan Nasional (BNSP, 2006), Kepatuhan Hukum merupakan salah satu aspek dalam ruang lingkup mata pelajaran Pendidikan Kewarganegaraan yang meliputi: Hakikat Hukum (pengertian, penggolongan, tujuan hukum), arti penting hukum dalam kehidupan bermasyarakat dan bernegara, kepatuhan terhadap hukum yang berlaku dalam behidupan bermasyarakat dan bernegara. Pemahaman erat kaitannya dengan belajar, dalam belajar peserta didik diajak membangun makna dan pemahaman, jika pemahaman baik maka hasil belajar juga baik (Misnawati, Asran \& Margiati, 2018). Adapun hukum itu merupakan aturan, tata tertib dan kaidah hidup. Akan tetapi, sampai saat ini belum ada kesepakatan yang pasti tentang rumusan arti hukum. Akan tetapi meskipun sulit merumuskan definisi yang baku mengenai hukum, di dalam hukum terdapat beberapa unsur, diantaranya: (1) peraturan mengenai tingkah laku manusia dalam pergaulan masyarakat, (2) peraturan itu dibuat dan ditetapkan oleh badan-badan resmi yang berwajib, (3) peraturan itu bersifat memaksa, (4) sanksi terhadap pelanggaran peraturan tersebut adalah tegas (Azwar, 2018). 
Rahardjo (2009) menjelaskan terdapat faktor-faktor yang menjadi sebab hokum dipatuhi oleh masyarakat: (1) kepatuhan (compliance), adalah mengharapkan adanya imbalan dan berusaha menghindari sanksi yang diakibatkan dari pelanggaran terhadap norma hukum; (2) identifikasi (identification), adalah apabila hukum dipatuhi, bukan hanya nilai instrinsiknya saja, tetapi supaya kehidupan bermasyarakat tetap terpelihara, terjalinya hubungan baik dengan aparat yang menjalankan norma hukum tersebut; (3) internalisasi (internalization), yaitu bila seseorang mematuhi kaidah-kaidah hukum karena secara intrinsik kepatuhan tadi mempunyai imbalan. Karena pendidikan, kebiasaan, kesadaran akan manfaat, dan identifikasi dirinya dalam kelompok, manusia akan patuh (Mardyawati, 2016). Di sekolah seringkali terjadi pelanggaran dan pertentangan akibat kurangnya tanggung jawab belajar dan disiplin terhadap tata tertib yang menyebabkab timbulnya suasana yang tidak tertib dan tidak teratur.

\section{METODE PENELITIAN}

Penelitian ini menggunakan metode korelasi. Alasan penggunaan metode ini dipilih karena sesuai dengan tujuan penelitian yang ingin dicapai, yakni ingin mengetahui seberapa besar hubungan antara variabel bebas pertama yaitu pemahaman tentang kepatuhan hukum $\left(\mathrm{X}_{1}\right)$, variabel bebas kedua yaitu dsiplin terhadap tata tertib sekolah $\left(\mathrm{X}_{2}\right)$, dan variabel terikat yaitu tanggung jawab belajar (Y). Penelitian kuantitatif dilakukan dengan tujuan untuk menguji hubungan atau pengaruh antar dua variable atau lebih, menguji kebenaran teori dan melakukan generalisasi agar dapat meramalkan adanya suatu gejala (Pudjiastuti, 2004).

Sebagaimana dikatakan oleh Pudjiastuti (2019) bahwa penelitian kuantitatif adalah untuk membuktikan ada tidaknya hubungan dan apabila ada, berapa erat hubungan, serta berarti atau tidaknya hubungan tersebut. Dengan pendekataan ini dapat dilihat antara variabel bebas (pemahaman tentang kepatuhan hukum) yang diberi simbol $\mathrm{X}_{1}$ dengan variabel terikat (tanggung jawab belajar) yang diberi simbol Y sebagai variabel yang dipengaruhi dan Pengaruh antara variabel bebas (disiplin terhadap tata tertib sekolah) yang diberi simbol $\mathrm{X}_{2}$ dengan variabel terikat (tanggung jawab belajar) yang disimbol Y sebagai variabel yang dipengaruhi.

\section{HASIL DAN PEMBAHASAN}

Berdasarkan hasil penelitian yang telah dilakukan, maka hasil penelitian disajikan dalam bentuk penyajian data yang sesuai dengan hasil pengukuran yang dilakukan sebelumnya. Penelitian ini terlaksan dikarenakan dari sampel yang dijadikan responden untuk diambil data-data tentang Pemahaman materi Kepatuhan hukum, Disiplin terhadap Tata Tertib Sekolah danTanggung jawab belajar siswa.pada materi Kepatuhan hukum disajikan pada tabel di bawah ini.

\section{Penyajian DataTanggung jawab belajar siswa(Y)}

Dari hasil pengisian kuesioner tanggung jawab belajar siswa yang dilakukan dengan 90 SMP Mutiara Depok. Berdasarkan data Tanggung jawab belajar siswa yang telah diperoleh maka setelah melalui perhitungan dapat diperoleh persentase nilai pengisian kuesioner Tanggung jawab belajar siswa(Y) sebagai berikut. 
Sahlan, Abduh \& Suidat

Tabel 1. Distribusi Frekuensi Kategori Tanggung Jawab Belajar Siswa

\begin{tabular}{cccc}
\hline No. & Interval Kelas & Frekuensi & Persentase \\
\hline 1 & $107-123$ & 6 & 6.67 \\
2 & $124-139$ & 7 & 7.78 \\
3 & $140-156$ & 27 & 30.00 \\
4 & $157-172$ & 32 & 35.56 \\
5 & $173-189$ & 18 & 20.00 \\
\hline & Jumlah & 90 & 100 \\
\hline
\end{tabular}

Nilai pada Tabel 1 merupakan hasil pengisian kuesioner tanggung jawab belajar siswa (Y). Disimpulkan bahwa dari 90 siswa SMP Mutiara Depok menunjukkan bahwa ada 6 orang siswa $(6,67 \%)$ memiliki kategori $107-123$, dan 7 orang siswa $(7,78 \%)$ memiliki kategori $124-139$, dan 27 orang siswa $(30,00 \%)$ memiliki kategori 140-156, dan 32 orang siswa (35,56\%) memiliki kategori 157-172, dan 18 orang siswa $(20,00 \%)$ memiliki kategori $173-189$. Untuk lebih jelasnya lagi dapat dilihat pada grafik berikut.

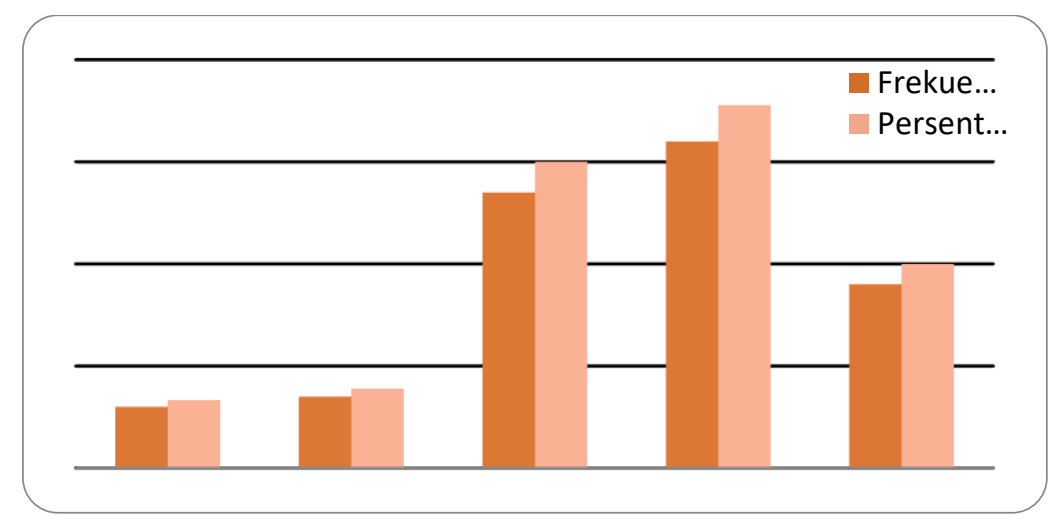

Gambar 1. Histogram Distribusi Skor Variabel Tanggung jawab belajar siswa

Selain dari interval dan frekuensi serta persetnase terdapat juga mean, median dan modus dari hasil perhitungan dengan hasil mean sebesar 157,04; Modus sebesar 99,70; dan Median sebesar 141,98.

\section{Penyajian Data Pemahaman Materi Kepatuhan Hukum (X1)}

Untuk mengetahui hasil prestasi $\left(\mathrm{X}_{1}\right)$ dilakukan tes Pemahaman materi Kepatuhan hukum dengan 90 SMP Mutiara Depok pada mata pelajaran PPKn dengan materi Kepatuhan hukum maka diketahui persentase Pemahaman materi Kepatuhan hukum sebagai berikut.

Tabel 2. Distribusi Frekuensi Kategori Pemahaman Materi Kepatuhan Hukum

\begin{tabular}{cccc}
\hline No. & Interval Kelas & Frekuensi & Persentase \\
\hline 1 & $17-21$ & 13 & 14.44 \\
2 & $22-27$ & 13 & 14.44 \\
3 & $28-32$ & 33 & 36.67 \\
4 & $33-38$ & 21 & 23.33 \\
5 & $39-43$ & 10 & 11.11 \\
\hline & Jumlah & 90 & 100 \\
\hline
\end{tabular}


Nilai pada Tabel 2 merupakan hasil tes Pemahaman materi Kepatuhan hukum $\left(\mathrm{X}_{1}\right)$. Disimpulkan bahwa dari 90 SMP Mutiara Depok menunjukkan bahwa ada 13 orang siswa $(14,44 \%)$ memiliki kategori $17-21$, dan 13 orang siswa $(14,44 \%)$ memiliki kategori $22-27$, dan 33 orang siswa $(36,67 \%)$ memiliki kategori 28-32, dan 21 orang siswa (23,33\%) memiliki kategori 33-38, dan 10 orang siswa $(11,11 \%)$ memiliki kategori39-43, dan untuk lebih jelasnya lagi dapat dilihat pada grafik berikut.

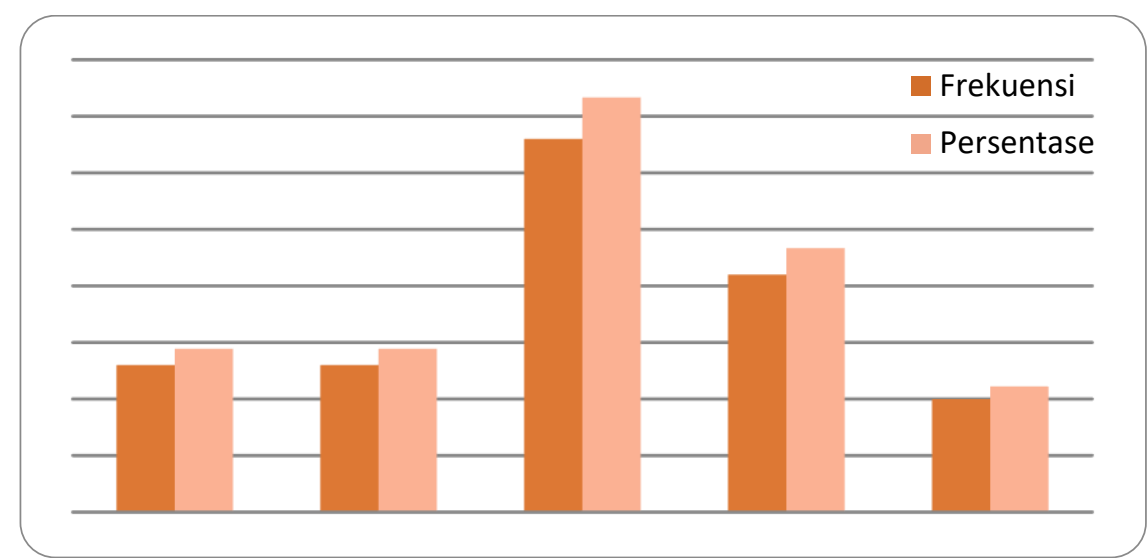

Gambar 2. Histogram Distribusi Skor Variabel Pemahaman Materi

Kepatuhan hukum

Selain dari interval dan frekuensi serta persentase terdapat juga mean, median dan modus dari hasil perhitungan dengan hasil mean sebesar 30,12; Modus sebesar 157,30; dan Median sebesar 34,13.

\section{Penyajian Data Disiplin terhadap Tata Tertib Sekolah (X2)}

Disiplin terhadap Tata Tertib Sekolah diukur kepada siswa yang melakukan dengan pengisian kuesioner Disiplin terhadap Tata Tertib Sekolah dengan 90 SMP Mutiara Depok dapat diketahui persentase nilai pengisian kuesioner Disiplin terhadap Tata Tertib Sekolah (X2) sebagai berikut.

Tabel 3. Distribusi Frekuensi KategoriDisiplin terhadap Tata Tertib Sekolah

\begin{tabular}{cccc}
\hline No. & Interval Kelas & Frekuensi & Persentase \\
\hline 1 & $95-111$ & 6 & 6.67 \\
2 & $112-128$ & 7 & 7.78 \\
3 & $129-145$ & 27 & 30.00 \\
4 & $146-162$ & 33 & 36.67 \\
5 & $163-179$ & 17 & 18.89 \\
\hline & Jumlah & 90 & 100 \\
\hline
\end{tabular}

Nilai pada Tabel 3 di atas yang merupakan hasil pengisian kuesioner Disiplin terhadap Tata Tertib Sekolah(X2). Disimpulkan bahwa dari 90 SMP Mutiara Depok menunjukkan bahwa ada 6 orang siswa $(6,67 \%)$ memiliki kategori 95-111, dan 7 orang siswa(7.78\%) memiliki kategori 112-128, dan 27 orang siswa(30,00\%) memiliki kategori129 -145, dan 33 orang siswa(36,67\%) memiliki kategori 146 - 
162, dan 17 orang siswa(18.89\%)memiliki kategori163-179. Untuk lebih jelasnya lagi dapat dilihat padagrafik berikut:

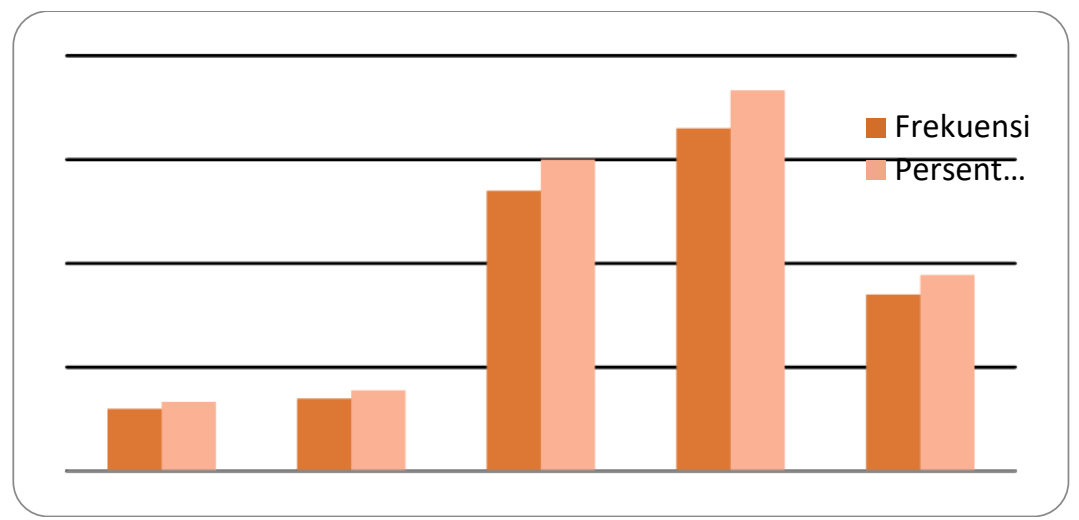

Gambar 3. Histogram Distribusi Skor Variabel Disiplin terhadap Tata Tertib Sekolah

Selain dari interval dan frekuensi serta persetnase terdapat juga mean, median dan modus dari hasil perhitungan dengan hasil mean sebesar 146,07; Modus sebesar 78,50; dan Median sebesar 130,98.

\section{KESIMPULAN}

Penelitian ini menyimpulkan sebagai berikut: Hasil tes pemahaman materi kepatuhan hukum $\left(\mathrm{X}_{1}\right)$. Disimpulkan bahwa dari 90 SMP Mutiara Depok menunjukkan bahwa ada 13 orang siswa (14,44\%) memiliki kategori 17-21, dan 13 orang siswa $(14,44 \%)$ memiliki kategori $22-27$, dan 33 orang siswa(36,67\%) memiliki kategori 28-32, dan 21 orang siswa (23,33\%) memiliki kategori 33-38, dan 10 orang siswa $(11,11 \%)$ memiliki kategori 39-43. Pemahaman materi kepatuhan hukum juga terdapat hubungan sebesar 92,21\% dengan keberhasilan dengan Pemahaman materi kepatuhan hukum pada materi kepatuhan hukum. Berorientasi pada hasil tersebut, keberhasilan Pemahaman materi kepatuhan hukum pada materi kepatuhan hukum atas 7,79\% ditentukan olehaspek lain di luar. Bisa dikatakan Pemahaman materi kepatuhan hukum siswa pada materi kepatuhan hukum lebih dari dari 1/2 (setengah) yang bisa dinyatakan memiliki hubungan antara tanggung tanggung jawab belajar siswa dengan Pemahaman materi kepatuhan hukum.

Hasil pengisian kuesioner disiplin terhadap tata tertib sekolah (X2). Disimpulkan bahwa dari 90 SMP Mutiara Depok menunjukkan bahwa ada 6 orang siswa $(6,67 \%)$ memiliki kategori $95-111$, dan 7 orang siswa $(7.78 \%)$ memiliki kategori 112-128, dan 27 orang siswa $(30,00 \%)$ memiliki kategori 129-145, dan 33 orang siswa $(36,67 \%)$ memiliki kategori $146-162$, dan 17 orang siswa (18.89\%) memiliki kategori 163-179. Disiplin terhadap tata tertib sekolah juga terdapat hubungan sebesar 98,83\% dengankeberhasilan dengan Pemahaman materi kepatuhan hukum pada materi kepatuhan hukum. Berorientasi pada hasil tersebut, Pemahaman materi kepatuhan hukum pada materi kepatuhan hukum sebesar 1,17\% ditentukan oleh aspek lain di luar. Bisa dikatakan Pemahaman materi kepatuhan hukum siswa pada materi kepatuhan hukum lebih dari 1/2 (setengah) yang bisa 
dinyatakan memiliki hubungan antara Disiplin terhadap tata tertib sekolah dengan Pemahaman materi kepatuhan hukum.

Terdapat hubungan signifikan antara pemahaman materi kepatuhan hukum dan disiplin terhadap tata tertib sekolah dengan tanggung jawab belajar siswa dilakukan dengan analisis korelasi ganda. Hasil analisis untuk mengetahui korelasi hubungan signifikan antara pemahaman materi kepatuhan hukum dan disiplin terhadap tata tertib sekolah dengan tanggung jawab belajar siswa, maka diperoleh $r_{\text {hitung }}$ sebesar 0,9942 Hasil tersebut kemudian dikonsultasikan dengan $r_{\text {tabel }}$ sebesar 0,205 ( $\alpha=0,05$ dan $\mathrm{N}=90$ ). Hasil konsultasi menunjukan bahwa $r_{\text {hitung }}=0,9942 \geq r_{\text {tabel }}=0,205$. Hal ini menunjukan bahwa ada hubungan signifikan pemahaman materi kepatuhan hukum dan disiplin terhadap tata tertib sekolah dengan tanggung jawab belajar siswa 90siswa SMP Mutiara Depok. Dari perhitungan koefisien determinan (KD) diketahui bahwa hubungan pemahaman materi kepatuhan hukum dan disiplin terhadap tata tertib sekolah dengan tanggung jawab belajar siswa adalah sebesar $98,85 \%$ sedangkan $1,15 \%$ ditentukan oleh faktor lain.

\section{REFERENSI}

Azwar, S. (2018). Eksistensi Alat Bukti dalam Pengadilan (Studi Komparatif Menurut Hukum Islam dan Hukum Positif di Indonesia). Qiyas: Jurnal Hukum Islam dan Peradilan, 3(2), 219-232.

BNSP. (2006). Standar Kompetensi dan Kompetensi Dasar. Jakarta: KEMENDIKBUD.

Damri, M. P., \& Putra, F. E. (2020). Pendidikan Kewarganegaraan. Jakarta: Prenada Media.

Fiana, F. J., Daharnis, D., \& Ridha, M. (2013). Disiplin siswa di sekolah dan implikasinya dalam pelayanan bimbingan dan konseling. Konselor, 2(3), 26-33.

Hernawati, N. (2017). Pengaruh Penerapan Sanksi Berjenjang Terhadap Kedisiplinan Siswa di SDN Mekarwangi I Kecamatan Cihurip Kabupaten Garut. Jurnal Pendidikan UNIGA, 2(1), 10-16.

Latifah, S. (2014). Integrasi Pendidikan Karakter Dalam Pembelajaran Di Sekolah. Jurnal ilmiah pendidikan fisika AL-Biruni, 3(2), 24-40.

Mardyawati, M. (2016). Implementasi Pendidikan Multikultural dalam Pembentukan Karakter Siswa. Ash-Shahabah, 2(2), 120-132.

Misnawati, M., Asran, M., \& Margiati, M. (2018). Peningkatan Hasil Belajar Siswa dalam Pembelajaran Pendidikan Kewarganegaraan Menggunakan Model Kooperatif Tipe Talking Stick. Jurnal Pendidikan dan Pembelajaran Khatulistiwa, 7(7), 1-12.

Narumi, S., \& Pudjiastuti, S. R. (2017). Hubungan Pemahaman Guru tentang UU Perlindungan Anak dan Persepsi terhadap Pelaksanaan HAM dengan Komitmen Penegakkan Tata Tertib Sekolah. Proceeding Seminar, Civic Education dalam Kompetisi Global: Pengembangan Civic Education dalam Menghantarkan Lulusan Untuk Menghadapi Kompetisi Global, Hotel Bumiwiyata Depok, 22-23 Desember 2017. ISBN: 978-60253635-0-4.

Pudjiastuti. S. R. (2004). Metode Penelitian Pendidikan. Jakarta: STKIP Kusuma Negara.

Pudjiastuti, S. R. (2019). Penelitian Pendidikan. Yogyakarta: Media Akademi. 
Rahardjo, S. (2009). Penegakan Hukum Sosiologis Suatu Tinjauan Sosiologis. Semarang: Genta Publishing.

Sujarwo, H. (2020). Pengaruh Pemberian Tugas Pekerjaan Rumah (PR) dan Ketersediaan Waktu Belajar terhadap Prestasi Belajar Siswa pada Mata Pelajaran Pendidikan Agama Buddha di Sekolah Menengah Pertama Negeri 2 Kaloran Kabupaten Temanggung Tahun Ajaran 2017/2018. BAHUSACCA: Pendidikan Dasar dan Manajemen Pendidikan, 1(1), 32-43.

Susanto, H. A. (2015). Pemahaman Pemecahan Masalah Berdasar Gaya Kognitif. Yogyakarta: Deepublish. 